\title{
THE IMPLEMENTATION OF GO FISH GAME IN IMPROVING STUDENTS' VOCABULARY
}

\author{
Hanafi Wibowo ${ }^{1}$, \\ *Universitas Islam As-Syafi'iyah, Jl. Jatiwaringin Raya no 12 Pondok Gede, Jakarta Timur, \\ Indonesia, Email: hanafiwibowo.fkip@uia.ac.id \\ Umi Laila Syarifah ${ }^{2}$, \\ **Universitas Islam As-Syafi 'iyah, Jl. Jatiwaringin Raya no 12 Pondok Gede, Jakarta Timur, \\ Indonesia,Email :Umilailasyarifah@gmail.com
}

\begin{abstract}
English is very important, since English is one of international language for communication. Although English in Indonesia is a second language, in fact not all Indonesians use it well. It was determined by their mastery on vocabularies. Therefore, one of the creative efforts to create fun learning is by using a vocabulary game called Go Fish. It uses Flash Card media. This study aims to explore whether the Flash Card or Go Fish game media can improve student's vocabulary or not. Experiment with Class Action Research (CAR) is used as the method of this study. The population of the study is fifth graders of Elementary School. This study uses 2 Cycles in which each cycle has 3 times. 2 material meetings or playing games and 1 meeting is a post test. In the first cycle the value of students is still below the KKM of the school, with an average of 62.5, while the English language standard of KKM School is 65. It is required to do the second cycle to achieve the KKM score of the school. And after doing the second cycle, the students' values have reached the School KKM score with an average of 81.75 . This means that there is a significant difference in the average value between the first and second cycles. Therefore, it shows that the media of Flash Card or Go Fish games can improve students' English vocabulary.
\end{abstract}

Key Word: Go Fish game, Vocabulary.

\section{INTRODUCTION}

English is one of the required lessons to learn. Since it is used as a lingua franca among global citizens. English is also referred to as a second language. English in Indonesia is referred as a foreign language. In learning English, vocabulary is one of the concideration.. English vocabulary is a key aspect to support four language skills. 
Concerning major part of language learning, students should be able to master the vocabulary as much as possible. Students will engage with learning when learning is done using fun strategies such as Go Fish games.

One of the main problems experienced by teachers or often happens in teaching English to students is that teachers do not prepare the material thoroughly. Sometimes teachers often use old methods such as lecture methods and do the exercises. It makes students feel bored and less fun. Therefore, the teacher is responsible in determining the appropriate method in teaching vocabulary that supports students to get understand easily.

Suyanto (2010 p. 169) says media is a necessary tool for learning English especially for children. Learning activities for teaching English for children should be accompanied by the use of media, especially visual. Media is anything that can be used to transmit messages from the sender to the receiver so as to stimulate the students' thoughts, feelings and interests and attention in such a way that the learning process takes place (Sadirman, Rahardjo and Haryono, 2009 p. 169).

This time the visual media that can be given to students one of them is the Go Fish game. Go Fish game is a kind of Flash cards media which is a learning media in the form of picture cards and comes with words. Flash Card is a small card containing images, text, or symbols that remind or guide students to something related to pictures that functioning to practice spelling and enriching the vocabulary Arsyad (2011 p.171).

What this research is trying to find is how the application of Go Fish game in teaching vocabulary and the extent to which Go Fish game can improve students' vocabulary. Because in reality the actual conditions are difficult for students to master vocabulary because of the ineffective strategies teachers use in teaching English. Therefore, with this research is expected to produce ideal conditions that must occur in students where students can enjoy the learning process and get the lessons (additional vocabulary) as possible.

Another purpose of this research is to find out how Go fish game can be implemented in teaching English vocabulary and to find out how far this game improves students' vocabulary.

The benefits of this research are students will feel happy in the learning process and get the ease of learning English. Teachers will also have new strategies to teach students easily and happily. And the result of this research is to recognize that Go Fish games are one of the most effective applied in the classroom to facilitate students in learning English vocabulary. 


\section{LITERATURE REVIEW}

\section{A. Definition of Vocabulary}

The basis of a language is a vocabulary, if there is no vocabulary then there is no language. The vocabulary represents a number of words in the language (Joklova,2009 p. 170). Vocabulary is a number of words that students know in a language. Vocabulary continues to grow with age as a useful tool of communication (Komachali and Khodareza, 2012 p. 170).

Mohammadnejad et al. (2012, p. 170) stated that the vocabulary is a basic element of a language which is used to label things like things,nature and verbs to explain the purpose of what to say. In oxford learner's pocket dictionary (2008), explains that vocabulary is; (1) the number of words the student knows and uses, (2) the number of words used in the language, (3) a word list consisting of words and their meanings. Komachali and Khodareza (2012 p. 170), he continues to say that the vocabulary usually develops and increases at every age level, and fundamentally serves as a communication tool.

\section{B. Media Flash Cards}

Media is anything that can be used to dispense the message from the sender to the recipient so that it can stimulate the students' thoughts, feelings, attention and interests and interests in such a way that the learning process takes place (Sadiman et al., 2009 p.171).

Flash cards are small cards containing images, text or symbols that remind or guide students to something related to images that can be used to practice spelling and enriching the vocabulary (Arsyad, 2011 p. 171). The size of the posts and images in the flash cards must be large enough so that all class members can see the content in the flash cards (Muhammadnejad et al., 2012 p. 171).

The flash card is a card in which there is a word, sentence or picture in it (Baleghizadeh and Ashoori, 2011 p. 171). Flash cards have two sides, the front of flash cards contain images and words while the back of flash cards is the meaning of the word. Flash cards are a very practical medium because they can be created together by teachers and students.Hotimah (2010 p. 171) argued that flash cards are a form of picture cards made with the use of photos or images, on the back there is a description of the image on the flash cards. The images contained in the flash cards will help improve the memory of the children, as the visuals have a greater effect on appreciating and understanding things than verbal / audio (Hudson et al in Carpenter and Olson, 2011 p. 171).Flash cards are a 
practical medium to help students and teachers in teaching and learning, especially in teaching flash cards (Nugroho et al., 2012 p. 171). With flash cards media can easily help students recall new vocabulary being studied, since flash cards have two sides ie words and their meanings (Khodashenas et al., 2014 p. 172).

Media flash cards have several advantages, as revealed by Susilana and Riyana (in Hotimah, 2010 p. 171) among others:

1) Easy to carry anywhere; due to its small size. It makes flash card flexibel to be used either in or outside the classroom.

2) Practical; which is seen from the way of making and its use, flash cards media very practical, in using this media teachers do not need to have special skills, this media need not also need electricity. If you want to use it we live to arrange the order of images in accordance with our wishes, make sure the exact position of the image is not reversed, and if it is used to stay stored again by tied or use a special box so as not to be scattered.

3) Easy to remember; the combination of images and text is enough to allow students to recognize the concept of something, to know the name of an object can be assisted with the picture, and vice versa to know the name of an object or concept by looking at the letter or text.

4) Fun; media flash cards in its use can be through the game. For example, students are competing to search for objects or certain names of flash cards that are stored randomly, by running students competing to search for a command. Flash cards are a very practical medium because they can be created together by teachers and students. One indication that visual imagery has the possibility of providing memory code.

Flash cards are a very practical medium because they can be created together by teachers and students. One indication that visual imagery has the possibility of providing effective memory codes is that students are usually easier at recognizing images than writing. Paivio (in Stephen, 2011 p. 172) stated that the reason why images become more effective is because the images provide other memory codes that are independent of the verbal code. He continues to say that the theory is called a double coding theory because it can be used in the process of reminders. Images tend to be memorable compared to concrete words, and are usually easier to store in memory than abstract words. 


\section{METHODOLOGY}

The method that will be used to analyze the data is classroom action research method. Action research is one form of research design, in action research the researcher describes, interprets and explains a social situation at the same time by making changes or interventions with the aim of improvement or participation.

The number of participants in this study are as many as 10-15 students of men and women. Students involved in this research are class V students in Islamic Elementary School As-Syafi'iyah 04. This research will be done on July 19, 2018 and treatment will takes 3 times meeting. Instruments to be used are observation sheets, interview sheets, and documents including Go Fish tests and games.

There are some procedures to be used in carrying out this research. First of all, the teacher ask permission to the principal to conduct research. After obtaining his permission is the teacher preparing all instruments; observation sheets, interview sheets, and documents including Go Fish tests and games. And then do some research. Teachers will teach them a selective topic related to their daily activities, then give them some related vocabulary to master. The teacher will show them the vocabulary, then explain the meaning of every word in a sentence. Then the teacher will show and tell them the procedure in using Go Fish games in class and ask them to participate in the game play until they seem to master the vocabulary. After the game is over, the teacher will ask how it feels, make observations and interviews, and test whether the game is effective or not.

After teachers teach them, and play games with them, teachers will use notes from observations and interviews to see how Go Fish games improve their vocabulary. Another result to be considered is their score in a paper test.

\section{FINDINGS AND DISCUSSION}

\section{Process of The Research}

\begin{tabular}{|l|l|l|}
\hline \multicolumn{1}{|c|}{ Cycle } & \multicolumn{1}{|c|}{ Meeting } & \multicolumn{1}{c|}{ Activity } \\
\hline $\begin{array}{l}\text { Enrich the } \\
\text { vocabulary of } \\
\text { shape, color, wild } \\
\text { animal, tame } \\
\text { animal, sea animal, } \\
\text { clothes, and }\end{array}$ & 1. Tuesday, 11th of September 2018 & $\begin{array}{l}\text { 1. } \begin{array}{l}\text { Playing Go Fish with } \\
\text { shape, color, wild } \\
\text { animal, tame animal, } \\
\text { vegetables, thinks } \\
\text { in the classroom },\end{array} \\
\text { sea animal, clothes, } \\
\text { vegetables themes. }\end{array}$ \\
$\begin{array}{l}\text { 2. Tuesday, 18th of September 2018 } \\
\text { Playing Go Fish with } \\
\text { think in the classroom, } \\
\text { think in the kitchen, } \\
\text { think in the bathroom, }\end{array}$ \\
\hline
\end{tabular}




\begin{tabular}{|l|l|l|}
\hline $\begin{array}{l}\text { thinks in the } \\
\text { kitchen, thinks in } \\
\text { the bathroom, food, } \\
\text { beverage, fruit, and } \\
\text { alphabet themes. }\end{array}$ & $\begin{array}{l}\text { food, beverage, fruit, } \\
\text { and alphabet themes. } \\
\text { Post test }\end{array}$ \\
\hline $\begin{array}{l}\text { Enrich the } \\
\text { vocabulary of } \\
\text { thinks in the living } \\
\text { room, toys, dark } \\
\text { colour, bright } \\
\text { colour, shape, part } \\
\text { of house, } \\
\text { transportation, } \\
\text { occupation, part of } \\
\text { body, musical } \\
\text { instrument, sports, } \\
\text { thinks in the } \\
\text { bedroom, jewelry, } \\
\text { and tools themes. }\end{array}$ & 1. Friday, 28th of September 2018 & $\begin{array}{l}\text { 1. Plaesday, 2nd of October 2018 } \\
\text { Playing Go Fish with } \\
\text { thinks in the living } \\
\text { room, toys, dark colour, } \\
\text { bright colour, shape, } \\
\text { part of house, and } \\
\text { transportation themes. }\end{array}$ \\
\hline
\end{tabular}

The assessment aspects that will be given to students in this research are as below,

\section{Vocabulary Skills Rubric}

\begin{tabular}{|l|l|}
\hline $\begin{array}{l}\text { Excellent } \\
100-90\end{array}$ & $\begin{array}{l}\text { Complete knowledge of vocabulary. Excellent at identifying word meaning. } \\
\text { No spelling problems. }\end{array}$ \\
\hline $\begin{array}{l}\text { Very Good } \\
89-80\end{array}$ & $\begin{array}{l}\text { Good vocabulary knowledge. Good at identifying word meaning. No } \\
\text { problems with spelling. }\end{array}$ \\
\hline $\begin{array}{l}\text { Good } \\
79-70\end{array}$ & $\begin{array}{l}\text { General vocabulary knowledge. Able to identify word meaning. Some } \\
\text { spelling problems without interfering understanding. }\end{array}$ \\
\hline $\begin{array}{l}\text { Fair } \\
69-60\end{array}$ & $\begin{array}{l}\text { Still acceptable vocabulary knowledge. Still able to identify word meaning. } \\
\text { Some spelling problems without fully interfering understanding. }\end{array}$ \\
\hline $\begin{array}{l}\text { Fail } \\
59 \text { or fewer }\end{array}$ & $\begin{array}{l}\text { Lack of vocabulary knowledge. Mispelled words. Unable to identify word } \\
\text { meaning. }\end{array}$ \\
\hline
\end{tabular}

\section{Process of Cycle 1}

\begin{tabular}{|c|c|}
\hline Planning & $\begin{array}{l}\text { Topic : The Various Vocabulary Part I } \\
\text { - Introduce various types of vocabulary and types. } \\
\text { - Playing Go Fish that uses cards to get to know various kinds of } \\
\text { vocabulary and types at each meeting. }\end{array}$ \\
\hline Action & $\begin{array}{l}\text { First meeting and Second meeting } \\
\text { - Give some examples of vocabulary and type. } \\
\text { - Explain how to play Go Fish for vocabulary. } \\
\text { - Monitor or pay attention to students who play Go Fish. } \\
\text { Third meeting } \\
\text { - Do the test in the form of writing the vocabulary they won or got. }\end{array}$ \\
\hline
\end{tabular}




\begin{tabular}{|c|c|}
\hline Observation & $\begin{array}{l}\text { Student : } \\
\text { - Many students are curious about the Go Fish game. many of them are } \\
\text { also interested to immediately try the vocabulary game. Although there } \\
\text { are some students who are confused and wondering about the game. } \\
\text { The Teacher: } \\
\text { - The teacher prepares the cards to be played. } \\
\text { - The teacher prepares a worksheet. } \\
\text { - The teacher monitors the course of the game. } \\
\text { Classroom situation : } \\
\text { - Classes become more lively and fun. } \\
\text { - Classes become more productive. } \\
\text { - Most students are active and very enthusiastic to participate. }\end{array}$ \\
\hline Reflection & $\begin{array}{l}\text { Strength : } \\
\text { - By playing Go Fish for vocabulary, students can improve their } \\
\text { vocabulary to add to their vocabulary. } \\
\text { - There is an increase or increase in vocabulary obtained by students. } \\
\text { Weaknesses : } \\
\text { - There are still students who are not too familiar with how to play the } \\
\text { game. } \\
\text { - There are still students who are confused about where to categorize the } \\
\text { vocabulary. }\end{array}$ \\
\hline
\end{tabular}

This is a table score of the first cycle.

\begin{tabular}{|c|c|c|c|c|c|c|c|}
\hline \multirow[b]{2}{*}{ No. } & \multirow[b]{2}{*}{ Name } & \multicolumn{5}{|c|}{ Aspects } & \multirow[b]{2}{*}{$\begin{array}{l}\text { Total } \\
\text { Score }\end{array}$} \\
\hline & & $\begin{array}{l}\text { Excellent } \\
(100-90)\end{array}$ & $\begin{array}{c}\text { Very Good } \\
(89-80)\end{array}$ & $\begin{array}{c}\text { Good } \\
(79-70)\end{array}$ & $\begin{array}{c}\text { Fair } \\
(69-60)\end{array}$ & $\begin{array}{c}\text { Fail } \\
\text { (59 or } \\
\text { fewer) }\end{array}$ & \\
\hline 1 & Rizqy & & & & 64 & & 64 \\
\hline 2 & Fadly & & & & & 59 & 59 \\
\hline 3 & Anin & & & & 62 & & 62 \\
\hline 4 & Alma & & & & 64 & & 64 \\
\hline 5 & Wildan & & & & 63 & & 63 \\
\hline 6 & Arul & & & & & 59 & 59 \\
\hline 7 & Pinky & & & & & 59 & 59 \\
\hline 8 & Adinda & & & 70 & & & 70 \\
\hline & & Mean & & & & & 62.5 \\
\hline
\end{tabular}

From the results above stated that the students' grades were not sufficient, the KKM of the schools was 62.5. The Cycle 2 to achieve the KKM of school is required.

Process of Cycle 2

\begin{tabular}{|l|l|}
\hline Planning & $\begin{array}{l}\text { Topic : The Various Vocabulary Part II } \\
\text { - Reintroducing various types of vocabulary and other types part II. } \\
\text { - Play Go Fish again using cards to get to know various types of } \\
\text { vocabulary and other types at each meeting. }\end{array}$ \\
\hline Action & First meeting and Second meeting \\
\hline
\end{tabular}




\begin{tabular}{|c|c|}
\hline & $\begin{array}{l}\text { - } \quad \text { Provide several examples of vocabulary and other types of part II } \\
\text { - Reminds you of how to play Go Fish for vocabulary. } \\
\text { - Start letting students play Go Fish independently. } \\
\text { Third meeting } \\
\text { - Do the test by answering the jumble words with difficulty. }\end{array}$ \\
\hline Observation & $\begin{array}{l}\text { Student: } \\
\text { - Students have begun to understand or understand how to play Go Fish. } \\
\text { Teacher: } \\
\text { - The teacher prepares the card to be played. } \\
\text { - The teacher prepares a worksheet. } \\
\text { - The teacher starts monitoring the game from afar. } \\
\text { Class situation: } \\
\text { - Classes become more lively and fun. } \\
\text { - Classes become more productive. } \\
\text { - Most students are active and very enthusiastic to participate. }\end{array}$ \\
\hline Reflection & $\begin{array}{l}\text { Strength : } \\
\text { - By playing Go Fish for vocabulary, students can increase their } \\
\text { vocabulary. } \\
\text { - There is an increase or increase in vocabulary obtained by students. } \\
\text { - Their vocabulary increases. } \\
\text { Weakness: } \\
\text { - Few students still lack the skills to play Go Fish. }\end{array}$ \\
\hline
\end{tabular}

This is a table score of the second cycle.

\begin{tabular}{|c|c|c|c|c|c|c|c|}
\hline & & \multicolumn{5}{|c|}{ Aspects } & Total \\
\cline { 3 - 7 } No. & Name & $\begin{array}{c}\text { Excellent } \\
\mathbf{( 1 0 0 - 9 0 )}\end{array}$ & $\begin{array}{c}\text { Very Good } \\
\mathbf{( 8 9 - \mathbf { 8 0 } )}\end{array}$ & $\begin{array}{c}\text { Good } \\
\mathbf{( 7 9}-\mathbf{7 0 )}\end{array}$ & $\begin{array}{c}\text { Fair } \\
\mathbf{( 6 9}-\mathbf{6 0 )}\end{array}$ & $\begin{array}{c}\text { Fail } \\
\mathbf{( 5 9} \text { or } \\
\text { fewer) }\end{array}$ & $\begin{array}{c}\text { Score } \\
\text { Score }\end{array}$ \\
\hline 1 & Rizqy & & & & 85 & & $\mathbf{8 5}$ \\
\hline 2 & Fadly & & & & & 78 & $\mathbf{7 8}$ \\
\hline 3 & Anin & & & & 82 & & $\mathbf{8 2}$ \\
\hline 4 & Alma & & & & 90 & & $\mathbf{9 0}$ \\
\hline 5 & Wildan & & & 75 & & $\mathbf{7 5}$ \\
\hline 6 & Arul & & & & & 72 & $\mathbf{7 2}$ \\
\hline 7 & Pinky & & & & & 72 & $\mathbf{7 2}$ \\
\hline 8 & Adinda & & & 100 & & & $\mathbf{1 0 0}$ \\
\hline & \multicolumn{2}{|c|}{ Mean } & & & & & $\mathbf{8 1 . 7 5}$ \\
\hline
\end{tabular}

After doing Cycle 2, the student's score has reached the KKM of School, which is 81.75. Based on significant values in vocabulary mastery, it can be concluded that the research is succesful.

From the results of the discussion meeting students during the research, they stated that they were interested in the Go Fish game. They also feel happy during the learning process. They feel they have the ease of learning English and can really improve or add the English vocabulary they have. 


\section{CONCLUSION}

Flash Card media is one of the media that is very easy to do in learning. Examples like this Go Fish game. Researchers conducted the first cycle which was declared unsuccessful. Therefore, the researchers conducted Cycle 2 to achieve school KKM. And it works. From this, it can be concluded that Go Fish games can increase students' vocabulary. The benefit for those who read this research is that besides getting new knowledge, you can try it for new research too. And other benefits in the field of teaching that can be used by teachers in school as one of the new strategies in learning English to be more lively and fun, and can improve students' vocabulary skills.

\section{REFERENCES}

Arsyad, A. (2011). Media Pembelajaran, Jakarta: Rajagrafindo Persada.

Baleghizadeh,S.\&Ashoori,A.(2011). The Impactof TwoInstructional Tehniques on EFLLearner's VocabularyKnowledge:FlashCards Versus WordList,Mextesol journal,35(2).

Fitriyani, E., \& Nulanda, P. Z. (2017). Efektivitas Media Flash Cards Dalam Meningkatkan Kosakata Bahasa Inggris.Journal.uinsgd.ac.id

Hotimah,E.(2010). PenggunaanMedia Flashcarddalam Meningkatkan Kemampuan Siswapada PembelajaranKosakata Bahasa InggrisKelasII MIAr-Rochman SamarangGarut,JurnalPendidikan,04(01).

Joklova,K. (2009).UsingPicturesin Teaching Vocabulary,Bachelor's thesis.MasarykUniversity Faculty ofEducation.DepartmentofEnglish LanguageandLiterature.Brno.

Khodashenas.M.R.,Farahani. S.K., \& Alisahi, Z.(2014).Flash Cards Versus Animate Cartoons:a ComparativeStudy inVocabulary Teaching and Learning,InternationalJournalof Language Learning andApplied Linguistics World(IJJLLALW),5(4).

Komachali,M.E.\&Khodareza,M.(2012). International EducationStudies the EffectofUsing Vocabulary Flash Card onIranian Pre-University StudentsVocabulary Knowledge, International Education Studies,5(3). 
Mohammadnejad, S., Nikdel,H., \& Oroujlou,N.(2012). Reactivating EFLLearners' WordKnowledge by Meansof TwoTechnique: Flashcardsversus Wordlist, InternationalJournalofLinguistic,4(4).

Nugroho,Y.S.,Nurkamto， J., \&Sulistyowati,H. (2012).Improving Students' VocabularyMasteryUsingFlash Cards, English Education Journal, 1(1).

Sadirman,A.S.,Rahardjo,R.,\& Haryono, A. (2009). Media Pendidikan, Jakarta: Rajagrafindo Persada.

Suyanto,K.K.E.(2010).EnglishforYoungLearners, Jakarta: BumiAksara. 